\title{
Rapid Analysis of Eukaryotic Bioluminescence to Assess Potential Groundwater Contamination Events
}

\author{
Zacariah L. Hildenbrand, ${ }^{1,2}$ Alexandra Osorio, ${ }^{3}$ Doug D. Carlton Jr., \\ Brian E. Fontenot, ${ }^{1,4}$ Jayme L. Walton, ${ }^{5}$ Laura R. Hunt, ${ }^{1,4}$ Hyppolite Oka, ${ }^{1}$ \\ Dan Hopkins, ${ }^{6}$ Bryan Bjorndal, ${ }^{3}$ and Kevin A. Schug ${ }^{1}$ \\ ${ }^{1}$ Department of Biology and Department of Chemistry and Biochemistry, The University of Texas at Arlington, \\ Arlington, TX 76019, USA \\ ${ }^{2}$ Inform Environmental, LLC, Dallas, TX 75206, USA \\ ${ }^{3}$ Assure Controls Inc., Vista, CA 92081, USA \\ ${ }^{4}$ Water Quality Protection Division, United States Environmental Protection Agency, Dallas, TX 75202, USA \\ ${ }^{5}$ SWCA Environmental Consultants, Arlington, TX 76006, USA \\ ${ }^{6}$ Geotech Environmental Equipment Inc., Carrollton, TX 75006, USA
}

Correspondence should be addressed to Kevin A. Schug; kschug@uta.edu

Received 17 February 2015; Revised 24 May 2015; Accepted 28 May 2015

Academic Editor: Athanasios Katsoyiannis

Copyright (c) 2015 Zacariah L. Hildenbrand et al. This is an open access article distributed under the Creative Commons Attribution License, which permits unrestricted use, distribution, and reproduction in any medium, provided the original work is properly cited.

\begin{abstract}
Here we present data using a bioluminescent dinoflagellate, Pyrocystis lunula, in a toxicological bioassay to rapidly assess potential instances of groundwater contamination associated with natural gas extraction. P. lunula bioluminescence can be quantified using spectrophotometry as a measurement of organismal viability, with normal bioluminescent output declining with increasing concentration(s) of aqueous toxicants. Glutaraldehyde and hydrochloric acid ( $\mathrm{HCl})$, components used in hydraulic fracturing and shale acidization, triggered significant toxicological responses in as little as $4 \mathrm{~h}$. Conversely, $P$. lunula was not affected by the presence of arsenic, selenium, barium, and strontium, naturally occurring heavy metal ions potentially associated with unconventional drilling activities. If exogenous compounds, such as glutaraldehyde and $\mathrm{HCl}$, are thought to have been introduced into groundwater, quantification of $P$. lunula bioluminescence after exposure to water samples can serve as a cost-effective detection and risk assessment tool to rapidly assess the impact of putative contamination events attributed to unconventional drilling activity.
\end{abstract}

\section{Introduction}

Unconventional drilling techniques, such as hydraulic fracturing and shale acidization, have made the extraction of oil and natural gas from previously inaccessible deep shale formations both practical and economically advantageous [1] . Hydraulic fracturing involves a highly pressurized injection of water, sand or ceramic-based proppants, and chemical additives to expand fissures in the shale formation to stimulate the release of trapped hydrocarbons. Shale acidization uses large quantities of hydrochloric and/or hydrofluoric acid under low pressure to dissolve sediments and solids, increasing the permeability of the shale formation. Overlying groundwater can become potentially contaminated by unconventional drilling activities through several direct and indirect mechanisms. Concerns about environmental stewardship, in conjunction with the prospect of using natural gas to achieve energy independence, have provided an impetus for a number of recent investigations exploring the potential effects of unconventional drilling on groundwater quality [24].

While many potential pathways leading to groundwater contamination have been proposed, it is difficult to predict the risk for an individual site given varying geological conditions and variability in unconventional drilling practices $[5,6]$. Here, we present an assay (QwikLite 200 Biosensor System, Assure Controls, Inc., Vista, CA, USA) using the bioluminescent dinoflagellate Pyrocystis lunula as a tool for 
TABle 1: Concentrations of selected endogenous groundwater constituents and exogenous chemicals and their effects on P. lunula bioluminescence after a 24-h exposure.

(a)

\begin{tabular}{lccccccc}
\hline & \multicolumn{3}{c}{ Arsenic } & \multicolumn{2}{c}{ Endogenous compounds } & \multicolumn{2}{c}{ Selenium } \\
$\begin{array}{l}\text { Concentration } \\
(\mathrm{mg} / \mathrm{L})\end{array}$ & $\begin{array}{c}\text { Percent } \\
\text { inhibition }\end{array}$ & $\begin{array}{c}\text { Concentration } \\
(\mathrm{mg} / \mathrm{L})\end{array}$ & $\begin{array}{c}\text { Percent } \\
\text { inhibition }\end{array}$ & $\begin{array}{c}\text { Concentration } \\
(\mathrm{mg} / \mathrm{L})\end{array}$ & $\begin{array}{c}\text { Percent } \\
\text { inhibition }\end{array}$ & $\begin{array}{c}\text { Concentration } \\
(\mathrm{mg} / \mathrm{L})\end{array}$ & $\begin{array}{c}\text { Percent } \\
\text { inhibition }\end{array}$ \\
\hline Control & 0 & Control & 0 & Control & 0 & Control & 0 \\
5 & 98 & 40 & 13 & 25 & 0 & 4000 & 62 \\
10 & 99 & 60 & 39 & 50 & 0 & 10000 & 59 \\
30 & 98 & 80 & 72 & 100 & 0 & 20000 & 0 \\
50 & 99 & 125 & 100 & 250 & 43 & 25000 & 0 \\
100 & 98 & 250 & 100 & 500 & 74 & - & - \\
\hline
\end{tabular}

(b)

Exogenous compounds

\begin{tabular}{lccc}
\multicolumn{2}{c}{ Glutaraldehyde } & & \\
Concentration $(\mathrm{mg} / \mathrm{L})$ & & HCl & Concens compounds \\
Control & Percent inhibition & Control & 0 \\
0.75 & 0 & 25 & 0 \\
1.5 & 0 & 50 & 0 \\
3 & 0 & 100 & 0 \\
5 & 0 & 200 & 55 \\
7.5 & 47 & 300 & 99 \\
\hline
\end{tabular}

the rapid characterization of groundwater quality, indicating both the presence and severity of toxicity. Moreover, we quantify $P$. lunula toxicological response to exogenous chemicals and endogenous groundwater constituents that have previously been linked to unconventional oil and natural gas extraction [7].

\section{Methods and Materials}

QwikLite experiments were performed according to ASTM method E1924 and are based on previously published methods [8]. Briefly, $22.5 \mathrm{~mL}$ of sample was adjusted to a salinity of 30 ppt using crystallized ocean salt. A negligible amount of sample dilution was observed and salt concentrations were confirmed by refractometry. A homogenous suspension of $4.0 \mathrm{~mL}$ P. lunula (obtained from Assure Controls Inc., Vista, California, USA) was added to each salinity-adjusted sample, gently mixed, and $3.25 \mathrm{~mL}$ of the mixture pipetted to each of six replicate cuvettes in the measurement cartridge and then incubated in a light box with a $12 \mathrm{~h}$ on/off light cycle. After $24 \mathrm{~h}$, the bioluminescent light output was measured using the QwikLite 200 Biosensor System instrument (spectrophotometer and microprocessor). All spectrophotometry data were represented as percent decline in light output of samples relative to total bioluminescence from control samples that were devoid of analyte (percent inhibition). Measurements with a value of zero to $10 \%$ correspond to no observed effect, values ranging from 20 to $40 \%$ require further review, and values between 50 and 100\% suggest significant organismal stress associated with toxicity. A decrease in bioluminescence greater than $50 \%$ is the result of cell death and/or the reallocation of cellular resources away from the enzymatic production of bioluminescence [8]. The coefficient of variation $(\mathrm{CV})$ was calculated as a function of light output observed in the six replicate measurements.

Individual solutions for arsenic, barium, glutaraldehyde, hydrochloric acid $(\mathrm{HCl})$, selenium, and strontium were prepared in $30 \mathrm{ppt}$ ocean salt solutions, for toxicological assessment of each analyte. Initial dosing and serial dilution measurements were taken to determine the concentration required to elicit a $50 \%$ inhibition of bioluminescence in vitro $\left(\mathrm{IC}_{50}\right)$ for each individual analyte under the standard protocol of a 24-h exposure ([8]; Table 1). Briefly, 0, 5, 10, 30, 50, and $100 \mathrm{mg} / \mathrm{L}$ concentrations of arsenic were tested, as were 0,40 , $60,80,125$, and $250 \mathrm{mg} / \mathrm{L}$ concentrations of barium; 0, 25, 50, 100,250 , and $500 \mathrm{mg} / \mathrm{L}$ concentrations of selenium; 0, 4000, 10000,20000 , and 25000 concentrations of strontium; 0, 0.75, $1.5,3,5$, and $7.5 \mathrm{mg} / \mathrm{L}$ concentrations of glutaraldehyde; and $0,25,50,100,200$, and $300 \mathrm{mg} / \mathrm{L}$ concentrations of $\mathrm{HCl}$. Measurements for each analyte at each concentration were performed using six replicates. $\mathrm{IC}_{50}$ values were interpolated graphically in reference to the decrease in light production observed at each of the five nominal analyte concentrations relative to the control samples ( $0 \mathrm{mg} / \mathrm{L}$ analyte).

Prepared solutions at these concentrations (Table 1) were also used for each individual analyte, in conjunction with 4-, 6-, 8-, 12-, 24-, 48-, 72-, and 96-h exposures. Timelapse $\mathrm{IC}_{50}$ values were interpolated graphically to determine the concentration responsible for a $50 \%$ reduction in light production during each of the 8 different exposure periods. 


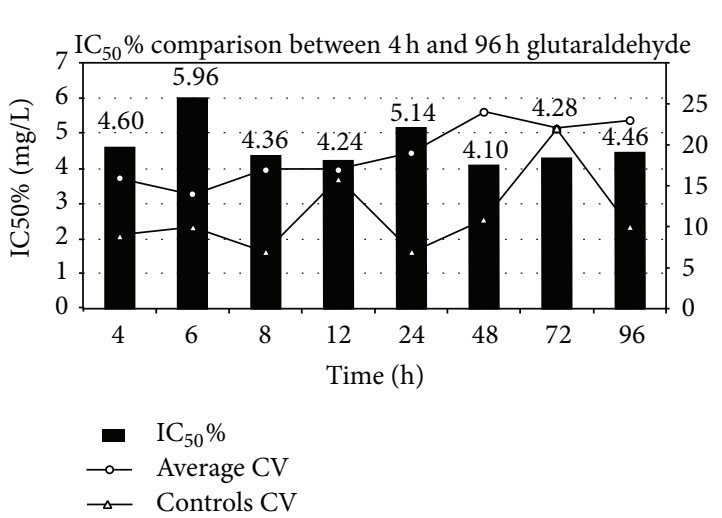

(a)

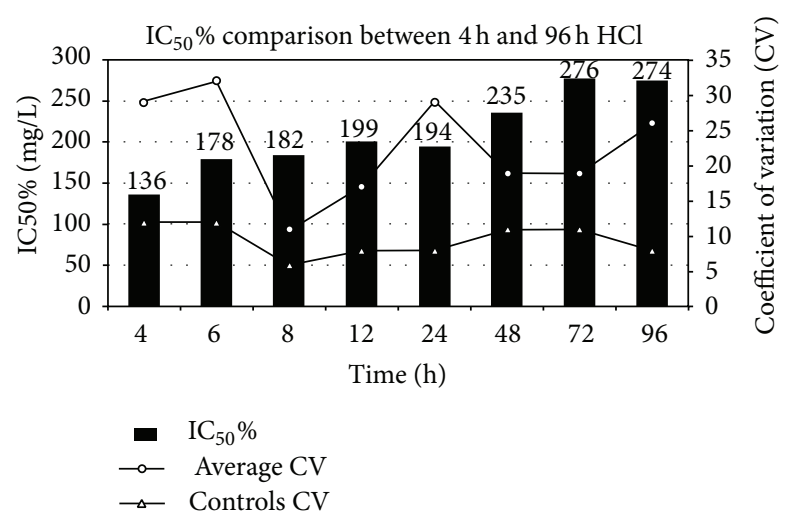

(b)

Figure 1: The concentration of (a) glutaraldehyde and (b) hydrochloric acid required for inhibition of light output in P. lunula by $50 \%$ during multiple exposure periods.

Measurements for each analyte at each concentration for each exposure period were performed using six replicates.

To test the efficacy of the assay for groundwater contamination evaluations, a total of 100 water samples were collected from private drinking water wells that draw from the Trinity, Woodbine, and Nacatoch aquifers in and around the Barnett Shale in North Texas as described previously [4]. To account for variability in purging flow rates between private wells, samples were collected after purging private wells for a minimum of 20 minutes to ensure that basic water quality parameters had stabilized (total dissolved solids, $\mathrm{pH}$, oxidation-reduction potential) (determined by a multiparameter YSI Sonde, Yellow Springs, OH, USA), indicating that fresh well water was being sampled. All private water well samples were collected from as close to the well pump as possible, bypassing any treatment or filtration systems. For each private well, we obtained four duplicate $40 \mathrm{~mL}$ water samples in glass vials with no headspace and kept them at $4^{\circ} \mathrm{C}$ during transport to the University of Texas at Arlington.

Elemental analysis of arsenic, barium, selenium, and strontium was performed using inductively coupled plasmamass spectrometry (ICP-MS) on a Varian 820 coupled with a SPS 3 Varian autosampler (Agilent, Santa Clara, CA, USA), using Argon as the plasma source. MS data were acquired in scan mode with 5 replicates and 30 scans per replicate as described previously [4].

\section{Results and Discussion}

Time-lapse analyses of $P$. lunula bioluminescence were performed in the presence of chemicals suspected to be constituents in the hydraulic fracturing fluid process [7]. Bioluminescent light production in P. lunula is reduced as toxicity increases, indicating that cultures are stressed and/or have died from toxin exposure [8]. Glutaraldehyde and $\mathrm{HCl}$ were selected for analysis, as they are commonly used in unconventional drilling [6]. Glutaraldehyde is used as an antimicrobial agent to inhibit bacterial growth throughout the well casing, while $\mathrm{HCl}$ is used to initiate fissures in shale rock [6]. Other potential components of hydraulic fracturing fluids were not tested due to their limited availability or poor solubility in water.

Glutaraldehyde elicited a 50\% reduction in P. lunula bioluminescence at a concentration of $5.14 \mathrm{mg} / \mathrm{L}$ after a 24-h exposure with consistent sensitivity throughout the 4-, 6-, 8-, 12-, 24-, 48-, 72-, and 96-h solution exposures (Table 2, Figure 1(a)).

These data are similar to the responses rendered by the herbicide diuron and the biocide tributyltin, with respective $\mathrm{EC}_{50}$ concentrations of 19.0 and $0.226 \mathrm{mg} / \mathrm{L}$ [9]. P. lunula was found to be most sensitive to $\mathrm{HCl}$ during the shortest exposure (Figure 1(b), $4 \mathrm{~h}$ ), in which $136 \mathrm{mg} / \mathrm{L} \mathrm{HCl}$ elicited a $50 \%$ reduction in bioluminescence.

These data corroborate previous observations that acids stress the cell to the point where bioluminescence is inhibited [10]. Notable hormesis was observed throughout the 96-h time course as $P$. lunula exhibited decreased sensitivity to $\mathrm{HCl}$ with increased exposure time $(136 \mathrm{mg} / \mathrm{L}$ vs. $274 \mathrm{mg} / \mathrm{L}$, during 4- and 96-h exposures, resp.).

The sensitivity of $P$. lunula to glutaraldehyde and $\mathrm{HCl}$ makes them useful indicators for risk assessment in alleged contamination events involving glutaraldehyde and $\mathrm{HCl}$. Hydraulic fracturing fluid has been documented to contain up to $0.01 \%$ glutaraldehyde by mass and $0.13 \% \mathrm{HCl}$ by mass, corresponding to approximate concentrations of 100 and $1300 \mathrm{mg} / \mathrm{L}$, respectively (http://www.fracfocus.org/). If glutaraldehyde and $\mathrm{HCl}$ are present at these concentrations, samples collected during a putative contamination event (e.g., a leak through a faulty casing or the mishandling of waste/produced water) would likely trigger a toxicological response in P. lunula, even during a short exposure period.

We also tested samples of private well water previously described as having high levels of arsenic, barium, selenium, and strontium [4]. Historically, these constituents are found at low concentrations in the sampled region [11-13]. However, elevated levels of these ions may be indirectly associated with unconventional drilling in the Barnett shale of North Texas [4]. P. lunula inhibition values ranged from 0 to 
TABLE 2: Concentrations of endogenous groundwater constituents and exogenous chemical compounds required to produce a $50 \%$ reduction in Pyrocystis lunula bioluminescence during eight different exposure periods.

(a)

\begin{tabular}{|c|c|c|c|c|c|c|c|}
\hline \multicolumn{8}{|c|}{ Endogenous compounds } \\
\hline \multicolumn{2}{|c|}{ Arsenic } & \multicolumn{2}{|c|}{ Barium } & \multicolumn{2}{|c|}{ Selenium } & \multicolumn{2}{|c|}{ Strontium } \\
\hline $\begin{array}{l}\text { Exposure } \\
\text { (hours) }\end{array}$ & $\begin{array}{c}\mathrm{IC}_{50} \\
\text { concentration* } \\
(\mathrm{mg} / \mathrm{L})\end{array}$ & $\begin{array}{l}\text { Exposure } \\
\text { (hours) }\end{array}$ & $\begin{array}{c}\mathrm{IC}_{50} \\
\text { concentration } \\
(\mathrm{mg} / \mathrm{L})\end{array}$ & $\begin{array}{c}\text { Exposure } \\
\text { (hours) }\end{array}$ & $\begin{array}{c}\mathrm{IC}_{50} \\
\text { concentration } \\
(\mathrm{mg} / \mathrm{L})\end{array}$ & $\begin{array}{c}\text { Exposure } \\
\text { (hours) }\end{array}$ & $\begin{array}{c}\mathrm{IC}_{50} \\
\text { concentration }^{*} \\
(\mathrm{mg} / \mathrm{L})\end{array}$ \\
\hline 4 & 2.55 & 4 & 40 & 4 & 200 & 4 & 5400 \\
\hline 6 & 2.53 & 6 & 65 & 6 & 451 & 6 & 7650 \\
\hline 8 & 2.52 & 8 & 68 & 8 & 493 & 8 & 10010 \\
\hline 12 & 2.65 & 12 & 88 & 12 & 314 & 12 & 3600 \\
\hline 24 & 2.55 & 24 & 68 & 24 & 307 & 24 & 3200 \\
\hline 48 & 2.50 & 48 & 68 & 48 & 400 & 48 & 4000 \\
\hline 72 & 2.55 & 72 & 62 & 72 & 378 & 72 & 4490 \\
\hline 96 & 2.55 & 96 & 70 & 96 & 359 & 96 & 5100 \\
\hline
\end{tabular}

(b)

\begin{tabular}{lccr}
\hline \multicolumn{2}{c}{ Exogenous compounds } & HCl \\
Exposure (hours) & $\begin{array}{c}\text { Glutaraldehyde } \\
\text { IC }_{50} \text { concentration }\end{array}$ (mg/L) & Exposure (hours) & IC $_{50}$ concentration $^{*}(\mathrm{mg} / \mathrm{L})$ \\
\hline 4 & 4.60 & 4 & 136 \\
6 & 5.96 & 6 & 178 \\
8 & 4.36 & 8 & 182 \\
12 & 4.24 & 12 & 199 \\
24 & 5.14 & 24 & 194 \\
48 & 4.10 & 48 & 235 \\
72 & 4.28 & 72 & 276 \\
96 & 4.46 & 96 & 274 \\
\hline
\end{tabular}

${ }^{*} \mathrm{IC}_{50}$ values were interpolated graphically from measurements collected with varying concentrations during each exposure period. Nominal exposure concentrations used at each time point are illustrated in Table 1.

$70 \%$ inhibition of bioluminescence with a mean value of $24 \%$ within the 100 private water wells that were sampled (Figure 2).

There was no significant correlation between percent inhibition values and the distance of the private water well to the nearest natural gas extraction site $(r=0.133, p>0.05)$, and there were no correlations between percent inhibition and the concentrations of arsenic, barium, selenium, and strontium. These data suggest that $P$. lunula either has a high tolerance for heavy metal ions or there are in situ matrix effects in groundwater samples mitigating the toxic effects of heavy metals on P. lunula.

$P$. lunula response was also tested in varying concentrations of arsenic, barium, selenium, and strontium. Measurements were taken during 4-, 6-, 8-, 12-, 24-, 48-, 72-, and 96-h exposures to assess $P$. lunula toxicological response over time. Initial $\mathrm{IC}_{50}$ determinations for arsenic, barium, selenium, and strontium revealed concentrations well above their respective drinking water maximum contaminant limit (MCL) and recommended levels (in the case of strontium) suggested by the US EPA of 10, 2000, 50, and $4000 \mu \mathrm{g} / \mathrm{L}$, respectively. Elevated tolerances were observed for each of the heavy metals throughout the 4- to 96 -h exposure spectrum with no evidence of decreased sensitivity or hormesis during the longer time periods (Table 2). Toxicological response in $P$. lunula has not been previously characterized in the presence of heavy metal ions; however, the $\mathrm{IC}_{50}$ values reported here are much greater than $\mathrm{EC}_{50}$ value of $0.128 \mathrm{mg} / \mathrm{L}$ reported for copper [9]. These data suggest that $P$. lunula has a tolerance for high levels of arsenic, barium, selenium, and strontium.

We used this assay to assess the toxicity of groundwater in private water wells located in the Barnett Shale region. Glutaraldehyde and $\mathrm{HCl}$ were found to elicit rapid toxicological responses ( $4 \mathrm{~h}$ exposure) at concentrations well below those found in many drilling fluid recipes. $P$. lunula response to glutaraldehyde was also found to be more sensitive and more rapid than equivalent observations previously recorded with Daphnia magna $\left(\mathrm{EC}_{50}\right.$ value of $18.0 \mathrm{mg} / \mathrm{L}$ after a $48-\mathrm{h}$ exposure) and Pimephales promelas ( $\mathrm{LC}_{50}$ value of $22 \mathrm{mg} / \mathrm{L}$ after a 96-h exposure; http://www.pesticideinfo.org/). While $P$. lunula exhibits tolerance for heavy metals, the observed responses to these ions are more sensitive than that of other bioassay test species. For arsenic, Procambarus clarkii, Aplexa hypnorum, and Morone saxatilis each exhibit $\mathrm{LC}_{50}$ values 


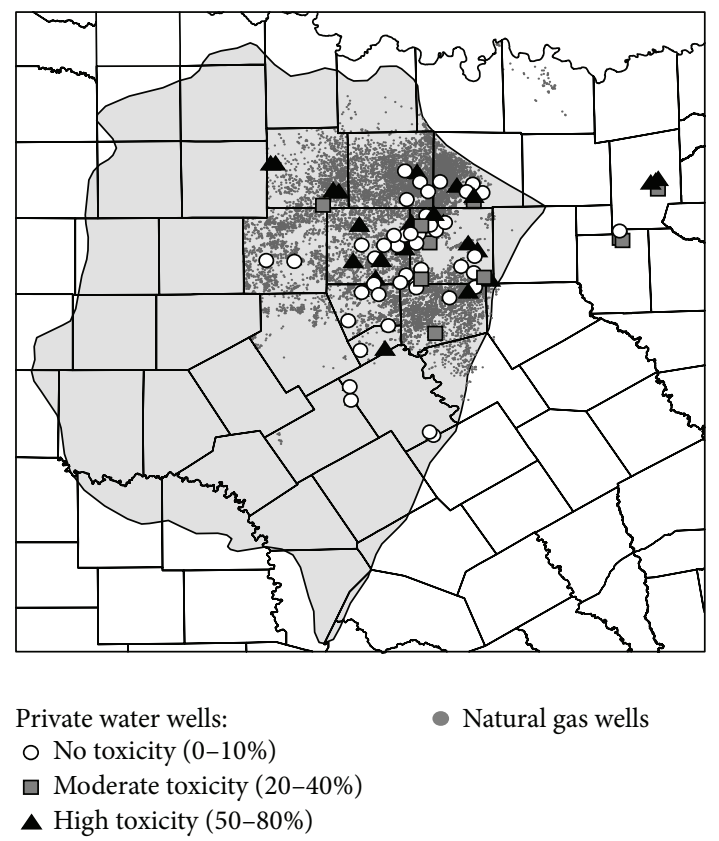

FIGURE 2: Map of private water well sampling sites and their respective toxicity values in relation to unconventional drilling sites in the Barnett Shale region (shaded area) in north Texas, USA.

orders of magnitude greater than that of $P$. lunula (1019, 24.5, and $30.0 \mathrm{mg} / \mathrm{L}$, resp.; http://www.pesticideinfo.org/). Common assays using P. promelas, D. magna, and Vibrio fischeri exhibit similar sensitivities to arsenic when compared to $P$. lunula $\left(\mathrm{EC}_{50}\right.$ values of $2.81,4.30$, and $1.52 \mathrm{mg} / \mathrm{L}$, resp.) but require at least $96 \mathrm{~h}$ of exposure to quantify a response (http://www.pesticideinfo.org/).

There are some potential issues to consider when using $P$. lunula to assess toxicity. For example, the addition of salt to freshwater samples to simulate a marine environment could influence the speciation and bioavailability of contaminants, so future studies should address how salinity affects the assay. We were also unable to obtain whole hydraulic fracturing fluid samples, and it is possible that matrix interactions in whole stimulation fluid could also influence toxicity results. Additionally, aquifer dilution could lead to low concentrations of contaminants during a contamination event, which could limit the detection ability of the assay. However, natural gas extraction in some regions requires shale acidization with high concentrations of acids [6], and this assay would be useful in detecting acid contamination.

These data show that the QwikLite algal bioluminescence test is rapid, cost-efficient, and sensitive to some compounds commonly associated with hydraulic fracturing. QwikLite may best be utilized as a preliminary screening and risk assessment tool, followed by a larger suite of focused analytical chemistry analyses if initial results indicate potential contamination. The QwikLite assay provides a response in as little as 4 hours, which also makes it desirable for rapidly assessing putative groundwater contamination events that could have political, legal, and human health consequences.

\section{Ethical Approval}

All experiments in this study were conducted in accordance with the laws of the United States of America.

\section{Disclaimer}

This work is not a product of the United States Government or the United States Environmental Protection Agency, and the authors did not do this work in any governmental capacity. The views expressed are those of the authors only and do not necessarily represent those of the United States or the United States Environmental Protection Agency.

\section{Conflict of Interests}

Alexandra Osorio and Bryan Bjorndal are employees of Assure Controls Inc. This company holds the exclusive commercial rights to the QwikLite 200 Biosensor System. QwikLite is the registered trademark of the US Government and exclusively licensed to Assure Controls Inc. No authors were financially compensated for this work, but Assure Controls Inc. did provide QwikLite testing materials free of charge under their scientific advocacy program.

\section{Authors' Contribution}

Zacariah L. Hildenbrand, Alexandra Osorio, and Doug D. Carlton Jr. contributed equally to this work.

\section{Acknowledgments}

The authors wish to thank Guido Verbeck at the University of North Texas for help with ICP-MS analyses. The authors also wish to thank Assure Controls Inc. for providing QwikLite testing materials and technical support. Most importantly, the authors would like to thank the participating well owners for their invaluable contribution to this research.

\section{References}

[1] Z. L. Hildenbrand, B. E. Fontenot, D. D. Carlton Jr., and K. A. Schug, "New perspectives on the effects of natural gas extraction on groundwater quality," GWF Discussion Paper 1339, Global Water Forum, Canberra, Australia, 2013.

[2] S. G. Osborn, A. Vengosh, N. R. Warner, and R. B. Jackson, "Methane contamination of drinking water accompanying gas-well drilling and hydraulic fracturing," Proceedings of the National Academy of Sciences of the United States of America, vol. 108, no. 20, pp. 8172-8176, 2011.

[3] R. B. Jackson, A. Vengosh, T. H. Darrah et al., "Increased stray gas abundance in a subset of drinking water wells near Marcellus shale gas extraction," Proceedings of the National Academy of Sciences of the United States of America, vol. 110, no. 28, pp. 11250-11255, 2013.

[4] B. E. Fontenot, L. R. Hunt, Z. L. Hildenbrand et al., "An evaluation of water quality in private drinking water wells near natural gas extraction sites in the barnett shale formation," Environmental Science and Technology, vol. 47, no. 17, pp. 1003210040, 2013. 
[5] J. E. Saiers and E. Barth, "Potential contaminant pathways from hydraulically fractured shale aquifers," Ground Water, vol. 50, no. 6, pp. 826-828, 2012.

[6] R. D. Vidic, S. L. Brantley, J. M. Vandenbossche, D. Yoxtheimer, and J. D. Abad, "Impact of shale gas development on regional water quality," Science, vol. 340, no. 6134, Article ID 1235009, 2013.

[7] US House of Representatives Committee on Energy and Commerce, Chemicals Used in Hydraulic Fracturing, United States House of Representatives Committee on Energy and Commerce, Washington, DC, USA, 2011, http://democrats.energycommerce.house.gov/sites/default/files/documents/Hydraulic-Fracturing-Chemicals-2011-4-18.pdf.

[8] D. Lapota, A. R. Osorio, C. Liao, and B. Bjorndal, "The use of bioluminescent dinoflagellates as an environmental risk assessment tool," Marine Pollution Bulletin, vol. 54, no. 12, pp. 1857-1867, 2007.

[9] J. L. Stauber, M. T. Binet, V. W. W. Bao et al., "Comparison of the QwikLite algal bioluminescence test with marine algal growth rate inhibition bioassays," Environmental Toxicology, vol. 23, no. 5, pp. 617-625, 2008.

[10] R. Hardleland and P. Nord, "Visualization of free-running circadian rhythms in the dinoflagellate Pyrocystis noctiluca," Mar Behav Physiol, vol. 11, no. 3, pp. 199-207, 1984.

[11] A. H. Welch, D. B. Westjohn, D. R. Helsel, and R. B. Wanty, "Arsenic in ground water of the United States: occurrence and geochemistry," Ground Water, vol. 38, no. 4, pp. 589-604, 2000.

[12] B. R. Scanlon, J. P. Nicot, R. Reedy et al., "Evaluation of arsenic contamination in Texas," Tech. Rep., Texas Commission on Environmental Quality Contract, Austin, Tex, USA, 2005.

[13] R. C. Reedy, B. R. Scanlon, J.-P. Nicot, and J. A. Tachovsky, "Unsaturated zone arsenic distribution and implications for groundwater contamination," Environmental Science and Technology, vol. 41, no. 20, pp. 6914-6919, 2007. 

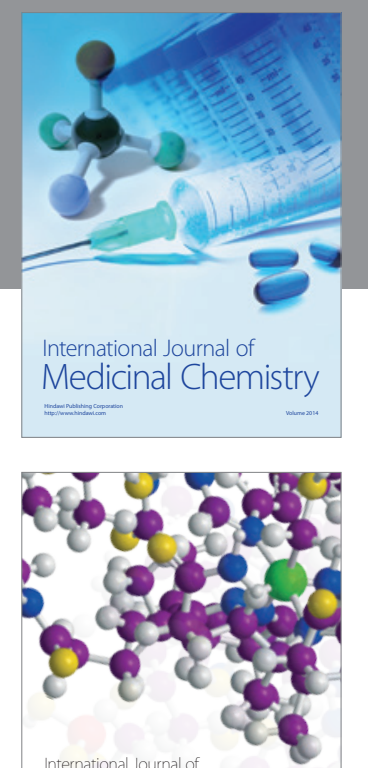

\section{Carbohydrate} Chemistry

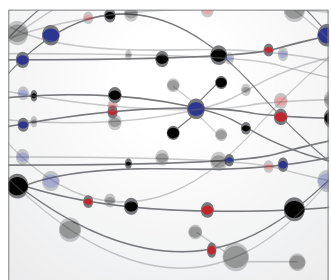

The Scientific World Journal
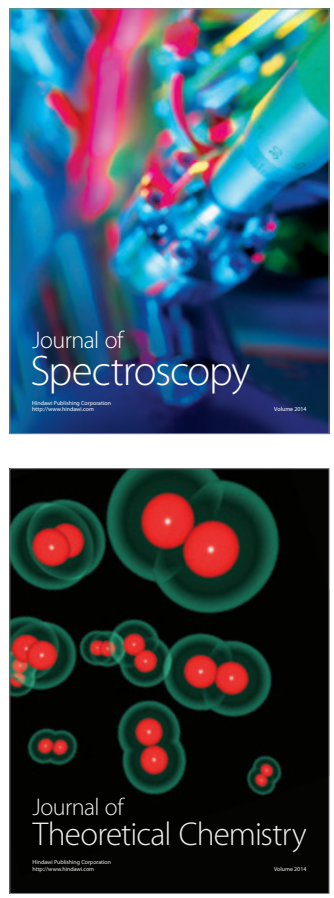
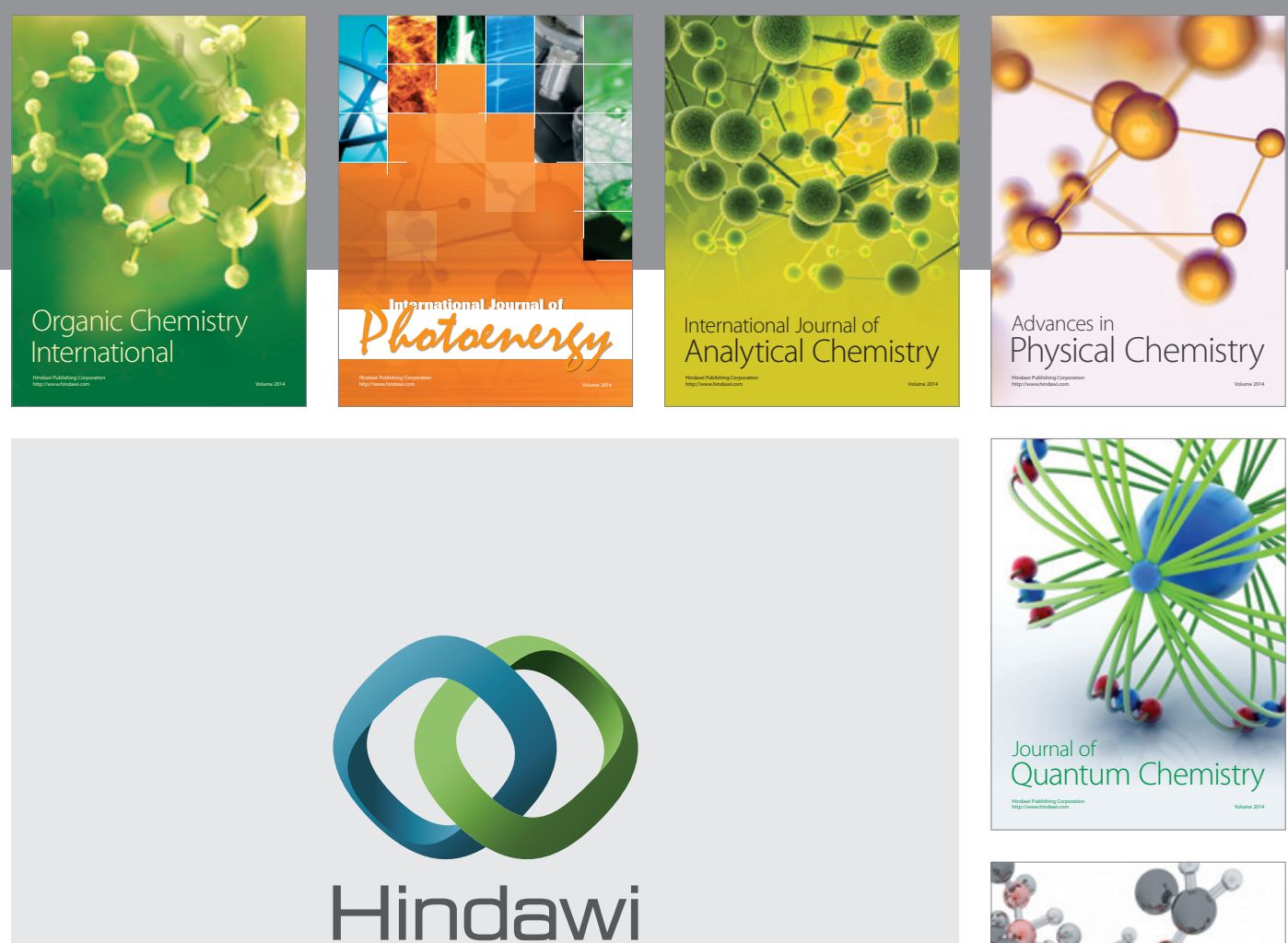

Submit your manuscripts at

http://www.hindawi.com

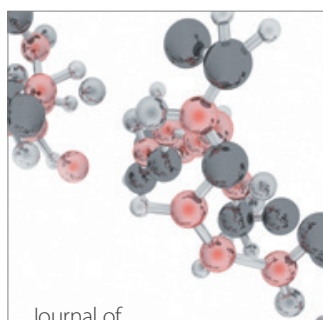

Analytical Methods

in Chemistry

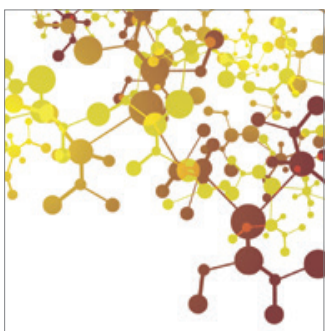

Journal of

Applied Chemistry

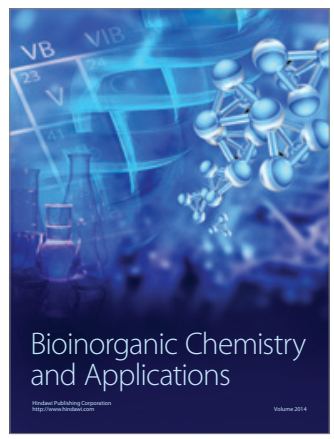

Inorganic Chemistry
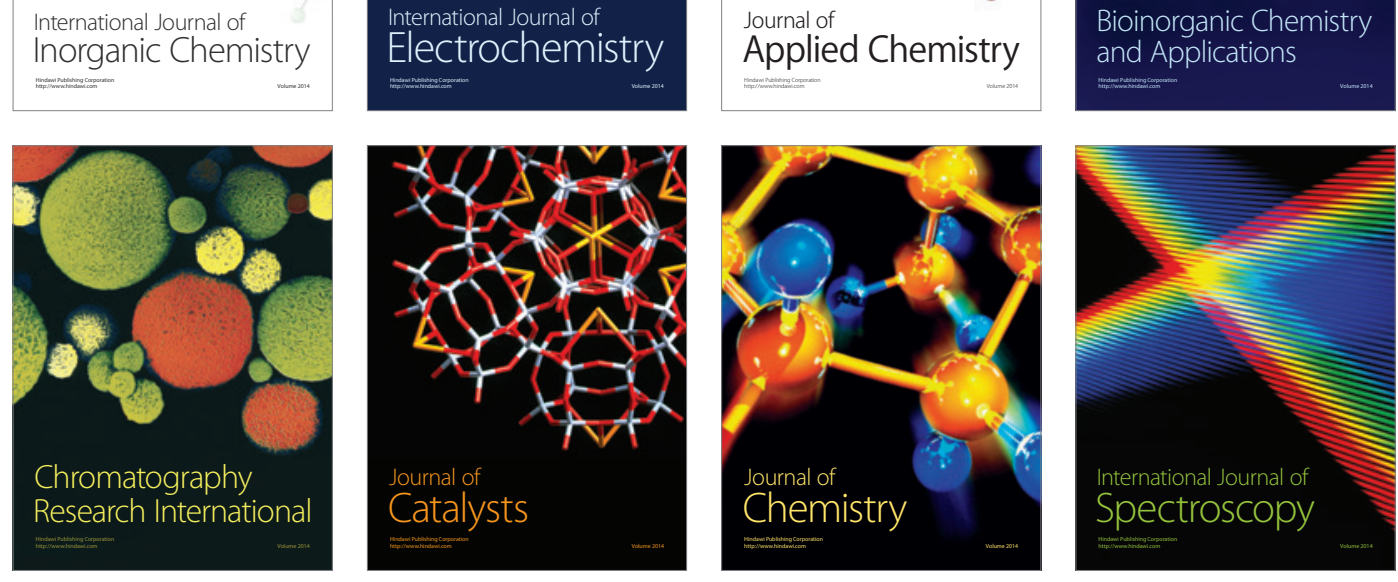